\section{㓞性的生态与景观系统构建 \\ 以三亚丰兴隆生态公园项目为例 \\ RESILIENT ECOLOGY AND \\ LANDSCAPE SYSTEMS OF THE \\ FENGXINGLONG ECOLOGICAL \\ PARK, SANYA}

\section{1 项目背景}

在中国经济飞速发展、城镇化进程大步向前的时代背景下, 城市 内涝、河流污染等城市病在城市滨水区域频发, 严重威胁着社会经济 和居民福禅

近30年来, 在传统城市开发模式下, 三亚的高密度城市建设使得 生态系统被割裂和碎片化, 并已成为制约三亚城市发展的重要因素。 2015年4月，中国住房和城乡建设部提出在三亚开展 “生态修复、城 市修补”工作，并选择将贯穿三亚主城区的三亚河与临春河作为本次

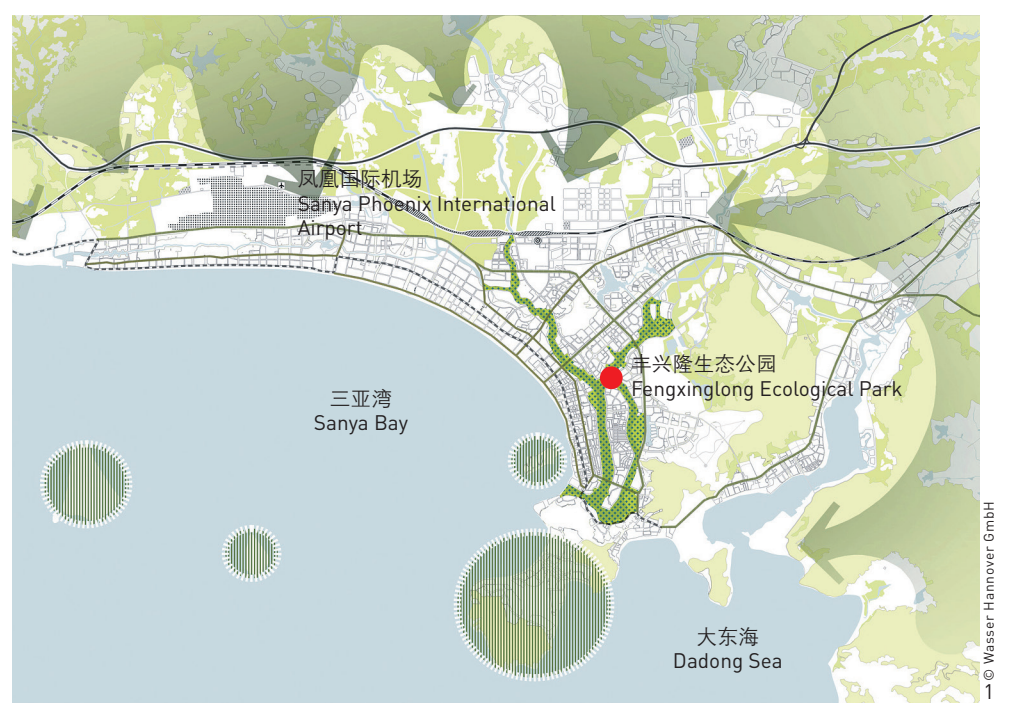

\begin{tabular}{|c|c|}
\hline https://ddi.org/10.15302/J-LAF-20180403 收福时间 RECEIVED DATE / 2017-10-09 & 中图分类号 / TU986.2 文献标识码 / A \\
\hline 郑能师 & ZHENG Nengshi \\
\hline 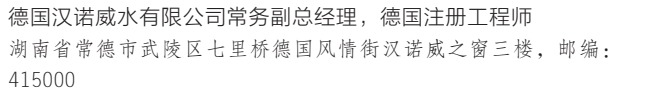 & $\begin{array}{l}\text { Deputy General Manager of Wasser Hannover GmbH; } \\
\text { Professional Engineer in Germany }\end{array}$ \\
\hline Nengshi.zheng@gmai 1.com & MA Haoran \\
\hline $\begin{array}{l}\text { 马浩然 } \\
\text { 中国城市规划设计研究院园林景观工程设计所副所长 }\end{array}$ & $\begin{array}{l}\text { Vice President of the Institute of Landscape Architecture } \\
\text { Design and Engineering, China Academy of Urban Planning and } \\
\text { Design }\end{array}$ \\
\hline & PENG Chiyan \\
\hline 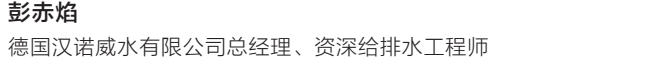 & $\begin{array}{l}\text { Director of and Senior Plumbing Engineer at Wasser Hannover } \\
\text { GmbH }\end{array}$ \\
\hline 刘苑 & LIU Yuan \\
\hline 德国汉诺威水有限公司常务副总经理 & Deputy General Manager of Wasser Hannover GmbH \\
\hline 罗布·格罗厄尔 & Rob GROTEWAL \\
\hline 德国汉诺威水有限公司资深景观设计师 & Senior Landscape Architect at Wasser Hannover GmbH \\
\hline $\begin{array}{l}\text { 乌维 ·克劳斯 } \\
\text { 德国汉诺威水有限公司资深水环境工程师 }\end{array}$ & $\begin{array}{l}\text { Uwe KLAUS } \\
\text { Senior Water Engineer at Wasser Hannover GmbH }\end{array}$ \\
\hline
\end{tabular}

摘要

近30年来, 在传统的城市开发模式下, 三 亚的高密度城市建设造成了生态系统的割裂和碎 片化, 并已成为制约三亚城市发展的重要因素。 2015年4月，中国住房和城乡建设部提出在三 亚开展 “生态修复、城市修补”工作，并选择将 贯穿三亚主城区的三亚河与临春河作为本次 “双 修”工作的核心空间抓手。丰兴隆生态公园项目 场地位于两河在中心城区的一处交汇处, 周边地 块为不同用地类型的城市片区与组团。多元的城 市界面、充足的绿地空间、纷杂的生态矛盾，使 之成为了三亚河流整治修复的“生态咽喉”。通 过一系列㓞性景观设计手段，丰兴隆生态公园不 仅发挥了休闲游怎之功用, 同时还起到了雨水收 集、调蓄、净化，对周边河流的污染物削减，以 及降低洪涝隐患等作用，并实现了生态修复和资源 的集约利用，成为了该汇水片区不可或缺的“城市 海绵”，以及综合性韧性生态公园的典范。

\section{关键词}

海绵城市建设；生态修复；韧性景观；红树林； 净化; 循环

整理 汪默英 田乐 张晶蕊 译 张徤 萨拉·雅各布斯

EDITED BY WANG Moying Tina TIAN ZHANG Jingrui TRANSLATED Angus ZHANG Sara JACOBS

\section{ABSTRACT}

In the past 30 years, Sanya has developed into a high-density city with fragmented ecosystems and bottlenecked urban development. In April 2015, the Ministry of Housing and UrbanRural Development proposed "Ecological Restoration and Urban Remediation" for Sanya and prioritized the Sanya and Linchun Rivers - two rivers that run through the central city - as core causes. The Fengxinglong Ecological Park project is located at the junction of the two rivers in downtown and its surroudings are occupied for various land uses. Diversified urban interfaces, abundant green space, and numerous ecological contradictions make the site critical for the remediation and restoration of waterways in Sanya. Through a series of resilient landscape design interventions,

Fengxinglong Ecological Park catches, stores, and purifies rainwater to reduce river pollution and flooding disasters in addition to offering recreational funtions. As a valuable "urban sponge" and comprehensive resilient ecological park, it has helped restore the historic

ecosystem and realized the intensive use of resources.

\section{KEY WORDS}

Sponge City Construction; Ecologica Purify; Circulation
Restoration; Resilient Landscape; Mangroves 


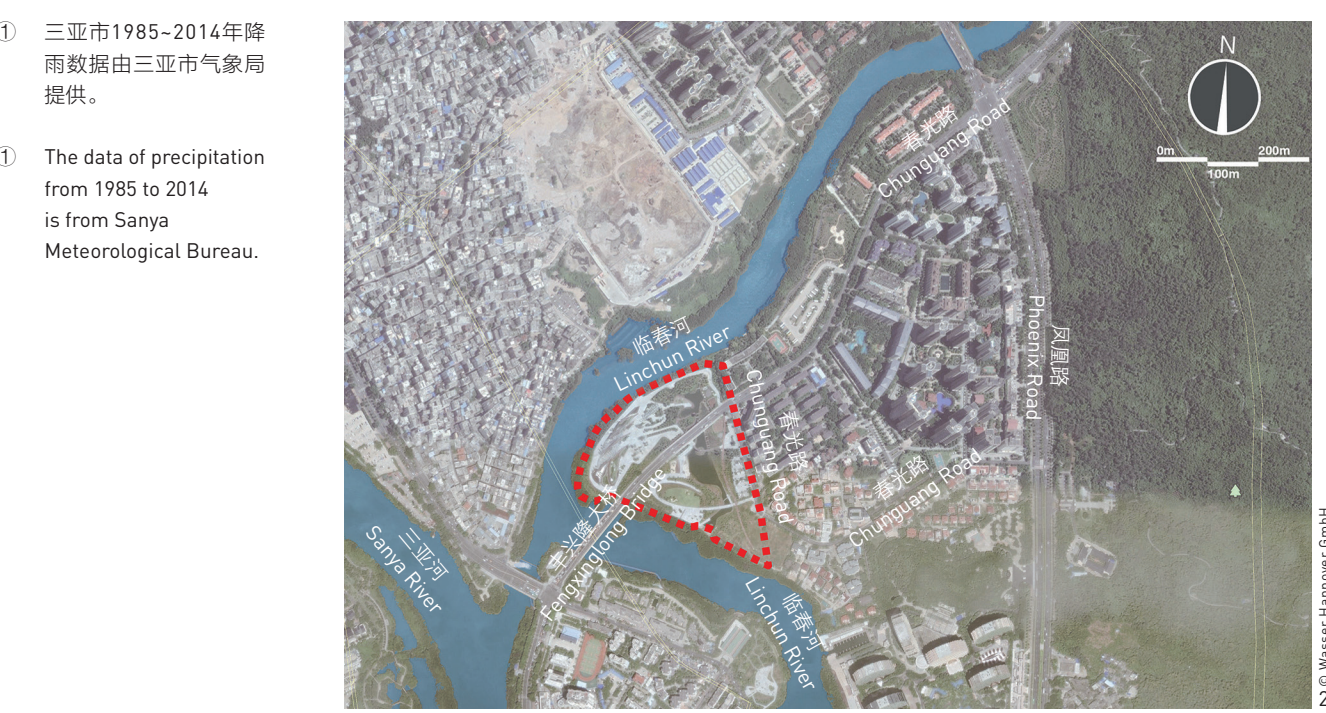

“双修”工作的核心空间抓手。丰兴隆生态公园项目场地位于两河在 中心城区的一处交汇处, 周边地块为不同用地类型的城市片区与组 团。该公园多元的城市界面、充足的绿地空间、纷杂的生态矛盾, 使 之成为了三亚河流整治修复的 “生态咽喉” [1]

\section{2 项目概况}

\section{1 区位概况}

三亚河、临春河发源于三亚北部山麓, 穿越中心城区, 于三亚湾 东侧交汇并流人南海（图1)。这两条河是三亚的母亲河, 也是三亚的 标志性自然景观，更是城市发展的历史见证者。潮汐河的特点为两河 沿岸的红树林提供了得天独厚的生长条件, 构建出一幅 “红树繁盛、 白路成群”的美丽画卷。[1]

丰兴隆生态公园项目场地占地面积 $9.54 \mathrm{~h} \mathrm{~m}^{2}$, 位于三亚河与临 春河交界处的三角洲地带（图2），自20世纪40年代至21世纪初一直 被作为盐场使用。随着城市的发展, 该区域先后建设了一系列住宅区, 盐场的功能也渐渐弱化, 并曾一度临时改建为公交停车场 (图3)。 交汇并流入南海。

丰兴隆生态公目项目场 地位于三亚河与临春河 交界处的二角洲地带。

Originating in the piedmonts north of Sanya, the Sanya River and Linchun River flow across the downtown Sanya and meet at the east side of the Sanya Bay before emptying into the South China Sea.

Fengxinglong Ecological Park located at the delta junction of Sanya River and Linchun River

\section{2 气候特征}

三亚属热带海洋性季风气候, 全年气温较高, 年降雨量和蒸发量 不均衡一一近 30 年来年平均蒸发量达 $2344 \mathrm{~mm}$, 而年平均降雨量则 为 $1522 \mathrm{~mm}$, 且降水分布严重不均, 每年5 10月的降雨量占年降雨量的 90\%左右，导致雨季时内涝频发，旱季时淡水资源贯乏 ${ }^{\mathbb{1}}$ 。

\section{3 区域汇水分析}

区域汇水包括两部分, 一部分来自公园本身, 另一部分来自周边 市政雨水管网（主要来自临近居民区）。公园汇水总面积为 $7.2 \mathrm{hm}^{2}$, 周

\section{Project Background}

The rapid economic and urban development of China has deteriorated waterfront environments, causing urban floods and river pollution that threaten social economy and human wellbeing.

In the past 30 years, Sanya has developed into a highdensity city with fragmented ecosystems and bottlenecked urban development. In April 2015, the Ministry of Housing and UrbanRural Development proposed "Ecological Restoration and Urban Remediation" for Sanya and prioritized the Sanya and Linchun Rivers - two rivers that run through the main city - as core causes. The Fengxinglong Ecological Park project is located at the junction of the two rivers in downtown and its surroundings are occupied for various land uses around it. Diversified urban interfaces, abundant green space, and numerous ecological contradictions make the site critical for the remediation and restoration of waterways in Sanya. ${ }^{[1]}$

\section{Project Introduction}

\subsection{Location}

Originating in the piedmonts north of Sanya, the Sanya River and Linchun River which flow across the downtown Sanya and meet at the east side of the Sanya Bay before emptying into the South China Sea (Fig. 1), are the mother rivers, history witnesses, and natural landmarks of Sanya. The unique growth conditions for the mangroves created by these two tidal rivers contributed to the flourishing mangroves habitats along the rivers that attract groups of egrets. ${ }^{[1]}$

Located at the delta junction of Sanya River and Linchun River, the Fengxinglong Ecological Park covers an area of $9.54 \mathrm{hm}^{2}$ (Fig. 2). From the 1940s to the beginning of the 21st century, the park site was a salt flat, but with the development of the city, it was transformed into a site of housing and parking (Fig. 3).

\subsection{Climate Conditions}

The tropical oceanic monsoon climate of Sanya causes high temperatures and unbalanced precipitation and evaporation. Using data from the past 30 years, the annual average precipitation is 1,522 millimeters with 2,344 millimeters of evaporation. Precipitation is mainly distributed between May and October, leading to floods during the rainy days and drought during the dry season ${ }^{(1)}$

\subsection{Regional Water Catchment}

The runoff from the park and the surrounding neighborhood 


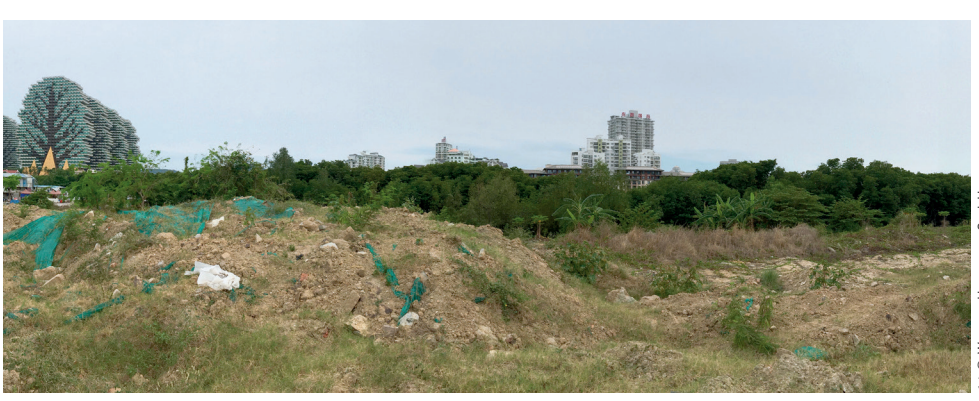

边市政雨水管网汇水面积约为 $31.3 \mathrm{hm}^{2}$; 有效径流总面积 ${ }^{[2]}$ 约为 $25 \mathrm{hm}^{2}$ （表1）。如果不对汇水区域雨水径流污染进行控制, 将会对场地水景 观水质产生较大影响。

\section{4 水资源平衡分析}

在全年大部分时间内, 公园水需求不能通过自然降水达到平衡, 水体补给来源为雨季雨水和旱季中水。而两种水源都无法达到公园景 观水质要求, 其中, 据三亚市环境监测站的检测数据显示, 场地中水 来源红沙污水处理厂的中水出水水质仅为 $\mathrm{I}$ 类 (表2 )。此外, 鉴于三 亚地区持续高温, 在高蒸发量环境下, 水分以蒸汽形式大量流失, 水 体营养物浓度提高，很可能使静水水体水质进一步恶化 ${ }^{[3]}$ 。

\section{5 潮汐及地下水影响分析}

场地紧邻三亚湾, 潮汐水位变化也会对设计产生直接影响。数据 分析显示, 受潮汐影响的河道水位最大波动达 $1.9 \mathrm{~m}$, 百年一遇最高潮汐 水位为 $2.55 \mathrm{~m}$ （潮高基准面为平均海平面以下 $90 \mathrm{~cm}$ ）。地下水水位处于 0.84 2.96m之间, 其中最高水位出现在 12 月雨季过后。由于场地内地下 水直接受到海水影响, 地下水水位波动可能会造成土地盐碱化, 而预 期建设的基础设施需要以淡水系统来保障植被灌溉和水景效果, 所以 在后续的设计中, 需要将公园水体和地下水进行隔离。同时, 在工程 方面还需要考虑新建地下结构抗浮问题。

\section{6 周边植物群落分析}

临春河红树物种丰富, 共有红树 15 科 16 种, 其中真红树植物有 8 科 8 种, 半红树植物有7 科 8 种, 另有伴生红树植物 5 科 5 种。在场地中, 正红树 (Rhizophora apiculate) 为群落优势种, 这是一种典型的热带 树种, 能够形成纯林; 场地中原有红树林宜林地约 $300 \mathrm{hm}^{2}$, 但场地周 边的城市开发、堤坝修建、水道渠化已将绝大部分林地占用作建设用 地, 对红树林生态群落造成了不可逆转的破坏。

\section{3 设计目标}

政府将项目定位为兼具游览观光、市民休闲、生态科普功能的 综合性城市公园。㓞性景观设计旨在为市民提供与自然和谐相处的空 forms a regional catchment area of $7.2 \mathrm{hm}^{2}$ (park) and $31.3 \mathrm{hm}^{2}$ (surrounding area) and a total effective runoff area ${ }^{[2]}$ of approximately $25 \mathrm{hm}^{2}$ (Table 1 ). Polluted runoff will degrade the water quality of the site unless caught and purified.

\subsection{Water Balance}

For most of the year, natural precipitation cannot match water demand in the park. Water stored during the rainy season and the reclaimed water from sewage plants can be used in the dry season, but they do not meet the water quality requirements of the landscape. According to test data from the Sanya Environmental Monitoring Station, the quality of the treated water from the Hongsha Sewage Plant where the site water came from is Class IV quality (Table 2). The water is largely lost to evaporation because of year-round hot weather and may lead to eutrophic deterioration of the water body ${ }^{[3]}$.

\begin{tabular}{c|c|c|c}
\multicolumn{5}{c}{$\begin{array}{c}\text { 表1: 场地汇水区域径流 } \\
\text { Table 1: Runoff of the Catchment }\end{array}$} \\
\hline $\begin{array}{c}\text { 土地类型 } \\
\text { Type of Land }\end{array}$ & $\begin{array}{c}\text { 总面积 } \\
\text { Total Area }\left(\mathbf{m}^{2}\right)\end{array}$ & $\begin{array}{c}\text { 径流系数 } \\
\text { Coefficient of Runoff }\end{array}$ & $\begin{array}{c}\text { 有效径流面积 } \\
\text { Effective Runoff Area }\left(\mathbf{m}^{2}\right)\end{array}$ \\
\hline $\begin{array}{c}\text { 公园绿地 } \\
\text { Park Green Space }\end{array}$ & 30,000 & 0.2 & 6,000 \\
\hline $\begin{array}{c}\text { 公园硬质铺装 } \\
\text { Park Pavement }\end{array}$ & 33,000 & 0.5 & 16,500 \\
\hline $\begin{array}{c}\text { 公园水系 } \\
\text { Park River Systerm }\end{array}$ & 9,000 & 1 & 9,000 \\
\hline $\begin{array}{c}\text { 临近居民区 } \\
\text { Neighborhoods }\end{array}$ & 313,250 & 0.7 & 219,275 \\
\hline $\begin{array}{c}\text { 总计 } \\
\text { Total }\end{array}$ & 385,250 & - & 250,775 \\
\hline
\end{tabular}

表2：红沙厂2016年第一季度中水出水水质月平均指标 (三亚市环境监测站) Table 2: Quality of the Water Discharged by the Hongsha Plant from January to March, 2016, Monitored by Sanya Environmental Monitoring Station

\begin{tabular}{c|c|c|c|c|c|c}
\hline $\begin{array}{c}\text { 监测指标 } \\
\text { Monitoring Indicator }\end{array}$ & $\begin{array}{c}\text { 化学需氧量 } \\
\mathbf{C O D}(\mathbf{m g} / \mathbf{L})\end{array}$ & $\begin{array}{c}\text { 生化需氧量 } \\
\mathbf{B O O D}(\mathbf{m g} / \mathbf{L})\end{array}$ & $\begin{array}{c}\text { 悬浮固体 } \\
\mathbf{S S}(\mathbf{m g} / \mathbf{L})\end{array}$ & $\begin{array}{c}\text { 氮氮 } \\
\mathbf{N H}_{3}-\mathbf{N}(\mathbf{m g} / \mathbf{L})\end{array}$ & $\begin{array}{c}\text { 总氮 } \\
\mathbf{T N}(\mathbf{m} / \mathbf{L})\end{array}$ & $\begin{array}{c}\text { 总磷 } \\
\mathbf{T P}(\mathbf{m g} / \mathbf{L})\end{array}$ \\
\hline $\begin{array}{c}\text { 一月 } \\
\text { January }\end{array}$ & 26 & 1.8 & 9 & 1.9 & 14.2 & 0.43 \\
\hline $\begin{array}{c}\text { 二月 } \\
\text { February }\end{array}$ & 23 & 1.8 & 8 & 2.7 & 13.6 & 0.42 \\
\hline $\begin{array}{c}\text { 三月 } \\
\text { March }\end{array}$ & 21 & 1.6 & 8 & 1.5 & 14 & 0.43 \\
\hline
\end{tabular}


间, 并为干旱、洪涝、城市热岛, 以及生物多样性缺失等问题提供解 决方案。

首先, 设计旨在创建能够㓞性地应对气候变化的 “城市海绵”。 依据2016年《三亚市海绵城市建设总体规划》, 丰兴隆生态公园建设 目标要求设计范围内年径流总量控制率为 $60 \%$, 设计降雨量 $25.3 \mathrm{~mm}$ 及以 下不外排, 溢流雨水管网设计可实现两年一遇暴雨经调蓄后安全排放。

其次, 设计期望创建丰富的自然栖息地, 不仅满足红树林等植被 的生存条件, 也可为包括白鹭在内的野生动物提供新的栖息家园。通 过对红树林生态系统进行恢复与保护, 可以减少雨季洪水对岸线的冲 刷, 并起到一定的水体净化功能。同时, 考虑到不同季节候鸟迁徙栖 息因素, 设计还规划出一条 “时隐时现的游览路线” (定期开放), 以减少游人活动对鸟类的影响。

再次, 针对三亚雨旱季分明, 以及白天日照强烈、夜晚凉爽宜人 的特殊气候条件, 创建滨河绿地的多样化利用方式。

最后, 要设计能够 “昼夜变化” 的景观设施。园内的景观设施 需要在白天提供遮阳和喷雾等降温功能, 在夜晚作为夜景照明主要节 点, 以兼顾市民活动与观光旅游的多样化需求。

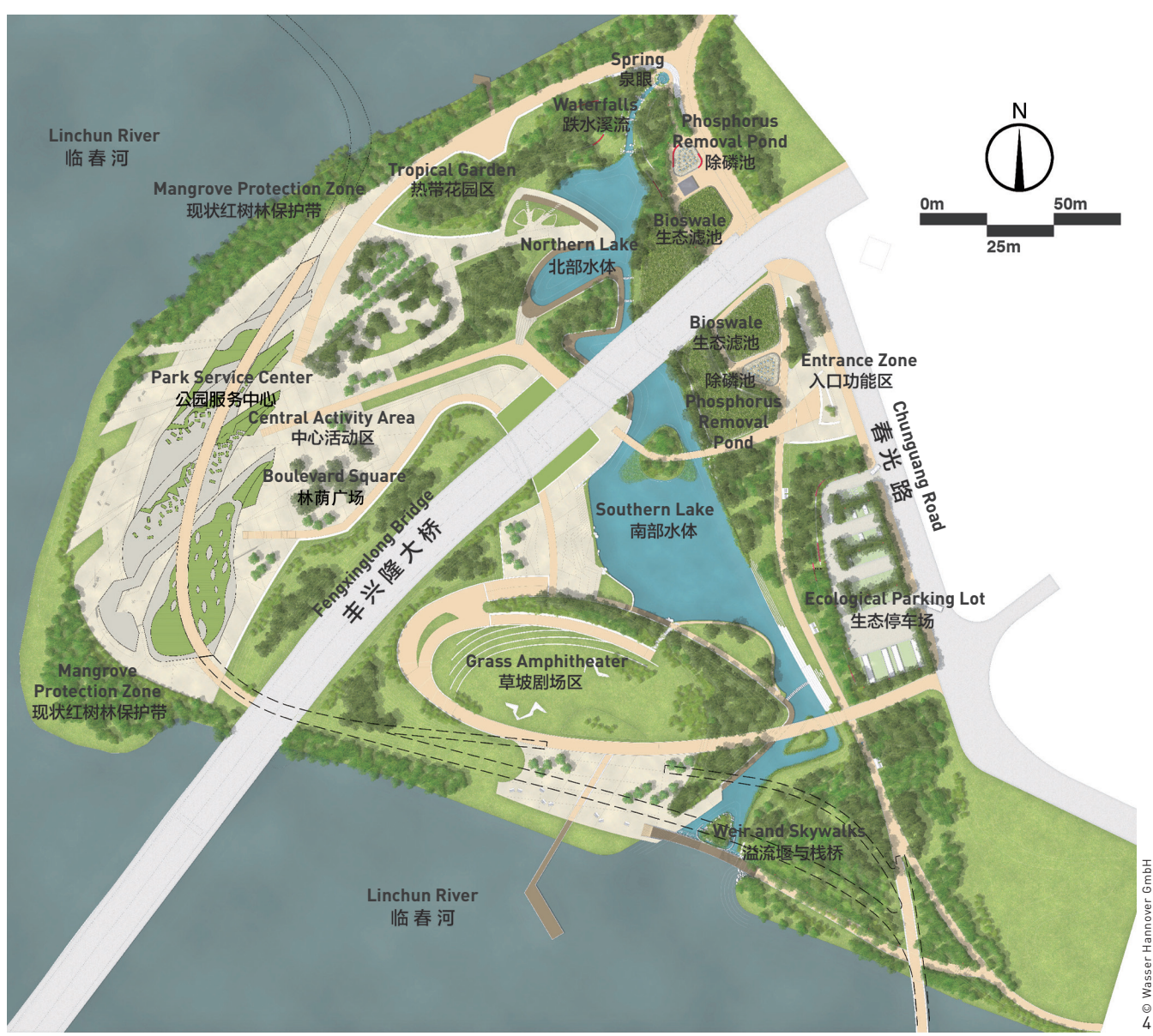

\subsection{Impacts of Tides and Groundwater}

The plan also takes tidal water change at the nearby Sanya Bay into consideration. According to data analysis, the maximum tidal fluctuation is 1.9 meters, while the highest tide level in a 100-year flood event reached 2.55 meters. The groundwater level is between 0.84 and 2.96 meters, with the highest water levels appearing after the rainy season in December. The park design isolates the park water from the groundwater because a freshwater system is needed to ensure that irrigation and waterscape are not affected by groundwater fluctuations, avoiding land salinization caused by seawater fluctuation. In addition, engineering problems such as antifloating of the new underground structures also need attentions.

\subsection{Peripheral Plant Community}

The mangrove along Linchun River hold 16 species from 15 families. Among this diversity, eight families (eight species) are true mangroves and seven families (eight species) are semimangroves. There are an additional five species of mangrove associated with five families. The dominate species is Rhizophora apiculate, a typical tropical tree which can form a pure forest. The original $300 \mathrm{hm}^{2}$ of mangrove forest and associated ecological communities have suffered irreversible damage due to land transformation caused by urban development, dam construction, and the channelization of waterways.

\section{Design Goals}

The Fengxinglong Ecological Park was defined to be a comprehensive urban park that combines sightseeing, citizen recreation, and ecological science. The resilient park landscape creates a space for citizens to live in harmony with nature, and provides solutions to droughts, floods, urban heat islands, and biodiversity loss.

First, the design aims to create "urban sponges" to enhance resilience to climate change. According to the Sponge City Construction Master Plan of Sanya City (2016), goals for the Fengxinglong Ecological Park are: 1) control $60 \%$ of total annual runoff; 2) completely absorb $25.3 \mathrm{~mm}$ of precipitation on site; 3) safely discharge the stored rainwater for a two-year rainstorm event.

Secondly, the design will create rich habitats to support mangroves and other vegetation and provide homes for egrets and other wild animals. Through restoration and protection of the mangrove ecosystem, shoreline erosion is reduced while water being purified. Tours and circulation with some parts inaccessible during breeding seasons through the park are 
主要设计策略包括:

(1) 水处理系统与生态水景相结合: 水净化处理与循环系统是公 园生态设计的核心。结合水净化处理与循环系统的处理流程和工程构 造形态, 将其转译为与公园整体景观相融合的生态水景观序列。

( 2) 驳岸修复与红树林生态系统恢复相结合：设计通过生态驳 岸改造、亲水空间设计、红树林补植, 使红树林生态系统兼具生态保 护、科普教育、游览观光等多种功能。

(3) 场地缝合与游赏体验相结合: 由于场地原本的绿地被河道和 城市道路严重割裂, 设计提出建设一条完整的、不间断的步行绿道环 廊系统, 串联起滨河绿色空间, 以形成丰富多样的游赏体验。

\section{4 空间布局}

基于各项场地条件分析和上述设计目标, 设计提出构建大、小两 个 “海绵” 体系, 并依此构建功能分区 (图4)。

(1) 中心活动区: 中心活动区是公园的核心区域, 在丰兴隆大桥 两侧设计缓坡地形, 不仅可以对桥上车行交通进行视觉遮挡, 还可以 在一定程度上减少噪音对公园的干扰; 中心活动区西部为公园服务中 心, 游人可以经由缓坡步道行至建筑屋顶之上, 并在此眺望园内和河 流的景致; 借由建筑与地形的围合设计的林荫广场则可供游人集会, 开展跳舞、太极等活动 ( 图5)。

（2）热带花园区: 热带花园区位于公园北侧, 设计通过几何缓坡 地形分割、围合空间, 形成一系列相对独立的小花园, 花园内种植热 带特色植物 (以兰花作为主要品种), 同时为游人提供了安静的休鄎 空间。

(3) 景观水系区: 公园东侧为景观水系区, 作为雨水收集、调 蓄、展示和亲水活动的主要区域; 丰兴隆大桥以北的水体以泉眼为源 头, 水沿着跌水溪流向南流下以进行曝气充氧 (图6); 丰兴隆大桥以 南为大型水面, 并且通过一道溢流堰与临春河相隔。

(4) 生态净化区: 景观水系区东侧为生态净化区, 分为位于地上 的 4 个生态滤池和 2 个除磷池 ( 图7), 同时设置了地下水处理措施, 包 括地下分流设施、雨水调蓄池和沉淀池, 水体在此得以生态净化, 随 后排入湖体。

( 5 ) 草坡剧场区: 草坡剧场区位于南部水体的西南侧, 以下 沉式开敞草地作为景观主体, 周边结合地形布置看台, 并利用高 大的热带植物围合空间 ${ }^{[4]}$ ( 图 8)。暴雨时期, 该草坡也可临时用于 蓄滞雨水。此外, 草坪北侧还设计了一座小型滨水广场, 可供游人亲 水嬉戏。

（6）现状红树林保护带: 保留并恢复场地周边的红树林群落, 并 为野生动物提供多样化栖息空间（图9）。

(7) 生态停车场: 生态停车场采用砂石填缝的弹石, 帮助雨水下 渗净化, 停车场周边设有植草沟和雨水花园, 用以消纳未被停车场吸 收的雨水径流。

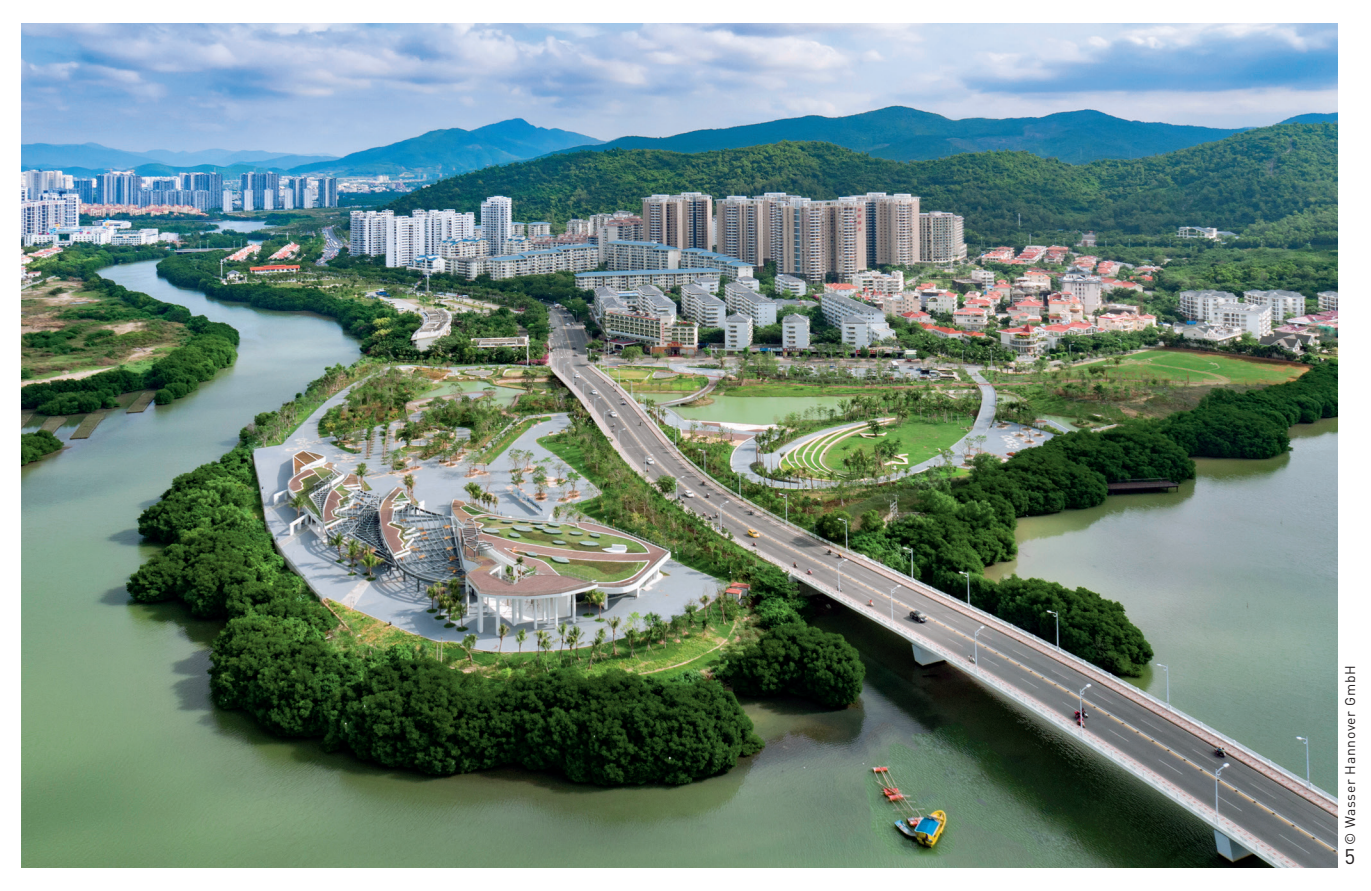

designed to reduce disturbance to migratory birds.

Thirdly, the design diversifies the riparian space to allow for variations in use between day and night and the rainy and dry seasons.

Finally, the landscape facilities need to have different functions for the day and night to meet the needs of residents and tourists. During the day, shade and water features help cool visitors while lighting activating the space at night.

The main design strategies include:

1) Combine water treatment system with ecological

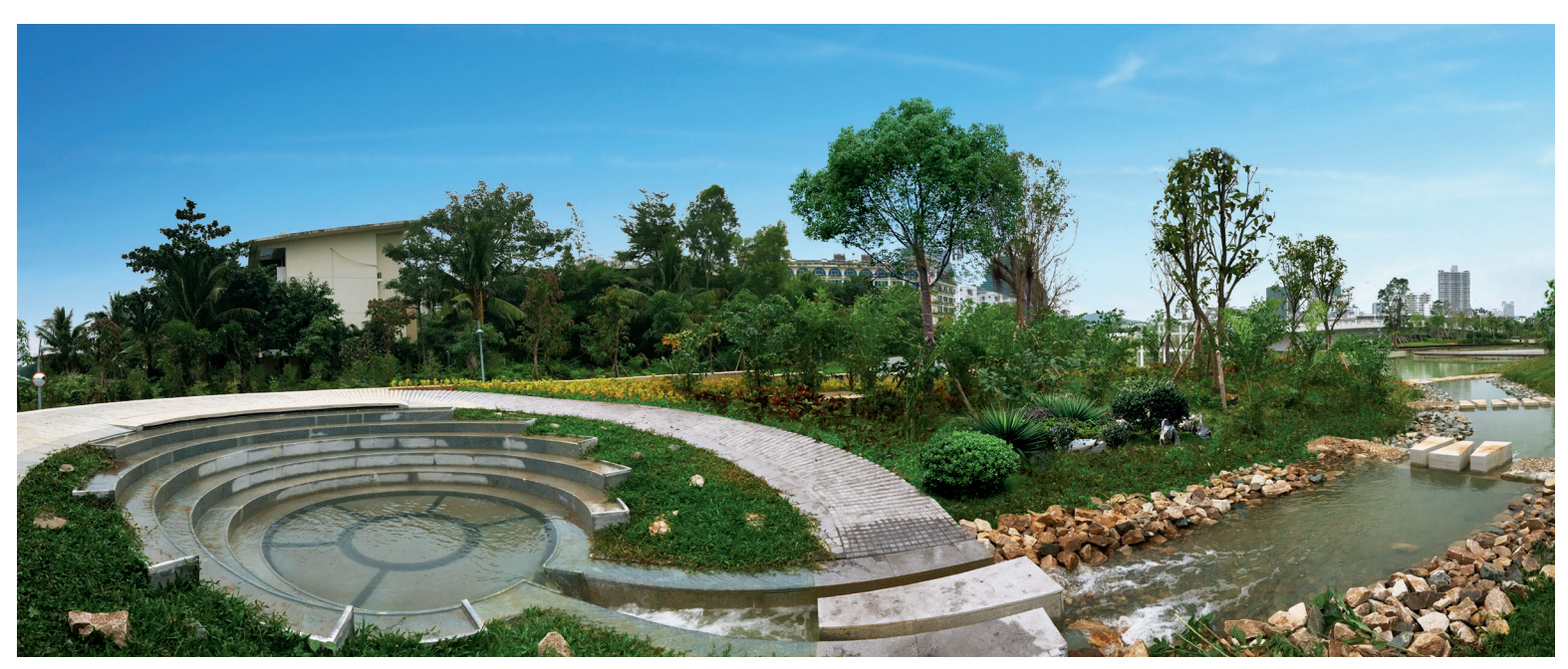




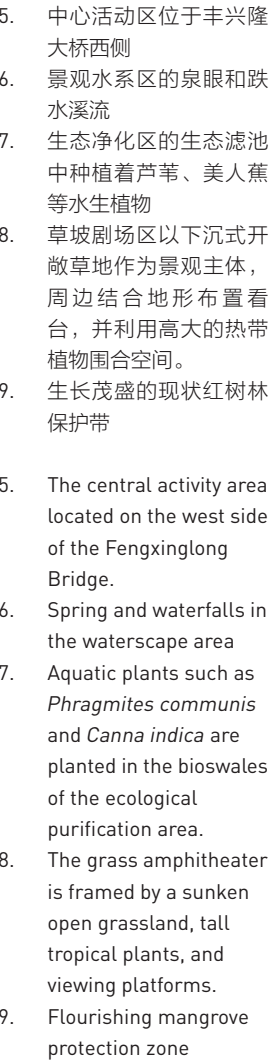

5. The central activity area located on the west side of the Fengxinglong

Bridge.

Spring and waterfalls in the waterscape area

Aquatic plants such as Phragmites communis and Canna indica are planted in the bioswales of the ecological purification area. The grass amphitheater is framed by a sunken open grassland, tall viepical plants, and

9. Flourishing mangrove protection zone

waterscape: The treatment process and engineering structure of the core water purification system are integrated into the overall landscape of the park, forming a series of ecological waterscapes.

2) Layer riverbank restoration with mangrove restoration: The design emphasizes mangrove restoration through riverbank reconstruction, hydrophilic space design, and mangrove replanting that provide space for protection, science education, and sightseeing.

3) Integration site construction with spatial experience: The design proposes to construct a complete and continuous green corridor to connect the riverside green spaces and provide a rich experience by reconnecting the space formerly separated by the river and urban roads.

\section{Spatial Layout}

Based on the site analysis and the design goals presented above, the design proposes to construct two "sponge" systems, one large and one small, that help define zones with different functions (Fig. 4).

1) The central activity area is the park's core. To block the site from the sight and noise of the Fengxinglong Bridge, the area is gently sloped on both sides. Through a series of ramps connecting the ground and the roof of the park service center, a building located in the west of the central activity area, visitors can take an overlook at the park and the river. The boulevard square set between the service center and the microtopography lets tourists gather for dancing, Tai Chi, and other activities (Fig. 5).
2) The tropical garden is in the north of the park. Planted with tropical plants such as orchids, this quiet and restful area is enclosed into a series of small gardens by gentle slopes.

3) The waterscape area located on the east side of the park collects and stores water on site while providing space for sightseeing and recreation. To the north of the Fengxinglong Bridge, the spring feeding water body flows through a series of waterfalls that aerate and oxygenate the water (Fig. 6). And to the south of the bridge, there is a large water surface (southern lake) with a weir at the south end which partitions the park lakes and Linchun River.

4) The ecological purification area to the east side of the waterscapes contains four bioswales and two phosphorus removal ponds (Fig. 7) with underground diversion facilities, storage tanks, and sedimentation tanks. The water body is purified here, and discharged into the lake.

5) The grass amphitheater to the southwest of the southern lake is framed by a sunken open grassland, tall tropical plants, and viewing platforms ${ }^{[4]}$ (Fig. 8). In a rainstorm event, this grassland can also store rainwater. In addition, the waterfront plaza on the north of the grass amphitheater is available for tourists to play with water.

6) The mangrove protection zone aims at preserving and restoring mangrove communities around the site, and providing diverse habitats for wildlife (Fig. 9).

7) The ecological parking lot is made of sand and gravel that helps rainwater infiltration and purification. The surrounding grass swales and rain gardens can absorb the rainwater from the parking lots.
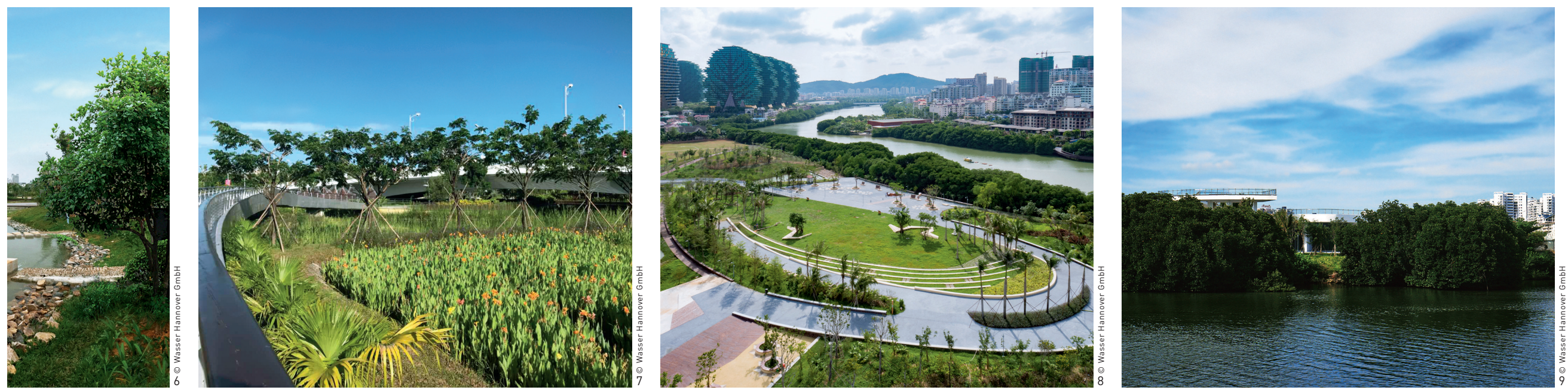


\section{5 技术实施}

\section{1 大海绵体系一一市政排水分区}

设计将周边小区约 $31.3 \mathrm{hm}^{2}$ 的海绵城市待改造区域排人市政雨水管 网的雨水纳人公园的水净化处理与循环系统中, 将其净化后排人水体 进行调蓄，并通过溢流外排人临春河（图10）。

周边小区的雨水通过市政雨水管网, 首先接人项目场地内的地下 雨水分流设施。在降雨过程中, 污染较为严重的初期雨水径流在地下 雨水调蓄池中被截流后，流人污水处理厂进行处理。在完成初期雨水 截流后, 溢流雨水首先进入沉淀池, 而后通过两个水百排人两级蓄水 型生态滤池中进行处理, 净化后流人场地内的景观水系。同时, 当南 部湖体超过设计水位时, 雨水会通过南端溢流堰排至临春河, 以保证 园区安全。这一大海绵系统实现了对周边市政雨水的净化、调蓄及削 峰减排, 大大降低了原有市政雨水管网对临春河道的污染和在洪峰季 节的防涝压力。

\section{2 小海绵体系一一公园内部排水分区}

通过多种手段处理公园内的雨水径流, 强化 “源头分散” 和 “慢 排缓释”, 使丰兴隆生态公园变得更加富有㓞性, 以确保公园真正在 涝时吸水、旱时吐水。

园区设计范围内年径流总量控制率为 $70 \%$, 降雨量 $35.4 \mathrm{~mm}$ 及以下 不外排。场地内屋面、道路、广场的初期雨水必须经过处理, 不得进 行弃流排放。溢流雨水管网设计可实现两年一遇雨水经调蓄后安全排 放。参照场地现状坚向将场地细分为若干个子汇水区域, 并主要采用 绿色屋顶、下凹绿地、雨水花园、生态草沟、植被缓冲带和透水铺装 等低影响开发设施, 将公园内的径流雨水进行有组织地下渗、滞留、 收集, 并排放至内部水系 ${ }^{[5]}$ 。

建成后的园区设计雨水设施总径流控制量为 $298.25 \mathrm{~m}^{3}$, 雨水蓄水模 块可控制径流量为 $100 \mathrm{~m}^{3[5]}$, 可实现总径流控制量为 $398.25 \mathrm{~m}^{3}$, 满足规划 控制目标要求。

\section{3 水源与水质保障系统}

场地内的水体总面积约为 $9000 \mathrm{~m}^{2}$, 公园绿地面积约为 $15000 \mathrm{~m}^{2}$ 。 园内水资源量与消耗量之间的年均差额达 $136095 \mathrm{~m}^{3}$ (表3)，从四月到 十一月, 汇水区域收集的雨水可以完全满足公园绿化浇灌和景观水体 补水需求; 但从十二月到次年三月, 由于降雨量小, 而蒸发量相对较 大, 需要额外进行补水。

场地内雨水调蓄空间主要由湖体构成。其中南部湖体面积约 $6260 \mathrm{~m}^{2}$, 调蓄深度为 $0.3 \mathrm{~m}$, 雨水调蓄空间为 $1878 \mathrm{~m}^{3}$; 北部湖体为跌水 水系, 不具备调蓄能力。利用南部湖体的调蓄空间, 收集到的雨水可 用于补给景观水系和植被灌溉用水; 在雨水量不能满足用水需求时, 也可以通过接人市政中水并由生态滤池和除磷池净化处理的方式进行 补给。[6|[1]

\section{Implementation}

5.1 Large Sponge System for Municipal Drainage

The design integrated the rainwater discharged into the municipal rainwater pipe network from the surrounding $31.3 \mathrm{hm}^{2}$ under-reconstruction neighborhoods into the park water purification system. The purified water flows into the lakes for storage and then into the Linchun River through the overflow (Fig. 10).

Rainwater from the municipal pipe network of the surrounding neighborhoods first goes through the underground diversion facilities at the project site. The initial runoff containing more serious pollution is intercepted into the underground storage tank and then flows into the sewage plant for treatment. After intercepting the initial runoff, the overflow rainwater enters the sedimentation tank and is discharged into two-stage bioswales for treatment through pumps. The purified water flows into the waterscapes, and overflows into the Linchun River through the weir when the water level exceeds the designed level to prevent flooding in the park. The large sponge system has realized the purification, storage and peak reduction of surrounding municipal rainwater, which greatly reduces pollution in the municipal system to Linchun River and provides flood control during the wet season.

\subsection{Small Sponge System for Park Drainage}

The runoff within the park area is treated by a variety of means which highlight dispersing from the source and discharging slowly, making the Fengxinglong Ecological Park become more resilient to absorb water when floody and reuse the stored water when dry.

Through this system, the park can control $70 \%$ of the annual runoff, and absorb rainwater when precipitation is less than 35.4 millimeters. All the first-flush on the roof, roads and squares in the park needs to be treated before discharged. The overflow pipes can accommodate and safely discharge a twoyear rainstorm. According to the topography of the site, the park was divided into many catchment zones. And low-impact facilities such as green roofs, a sunken grassland, rain gardens, bioswales, vegetated buffers, and permeable pavement, can infiltrate, retain, collect, and discharge water from the park into the lakes ${ }^{[5]}$
10. 大海绵体系技术路线

10. Treatment process of the large sponge system 


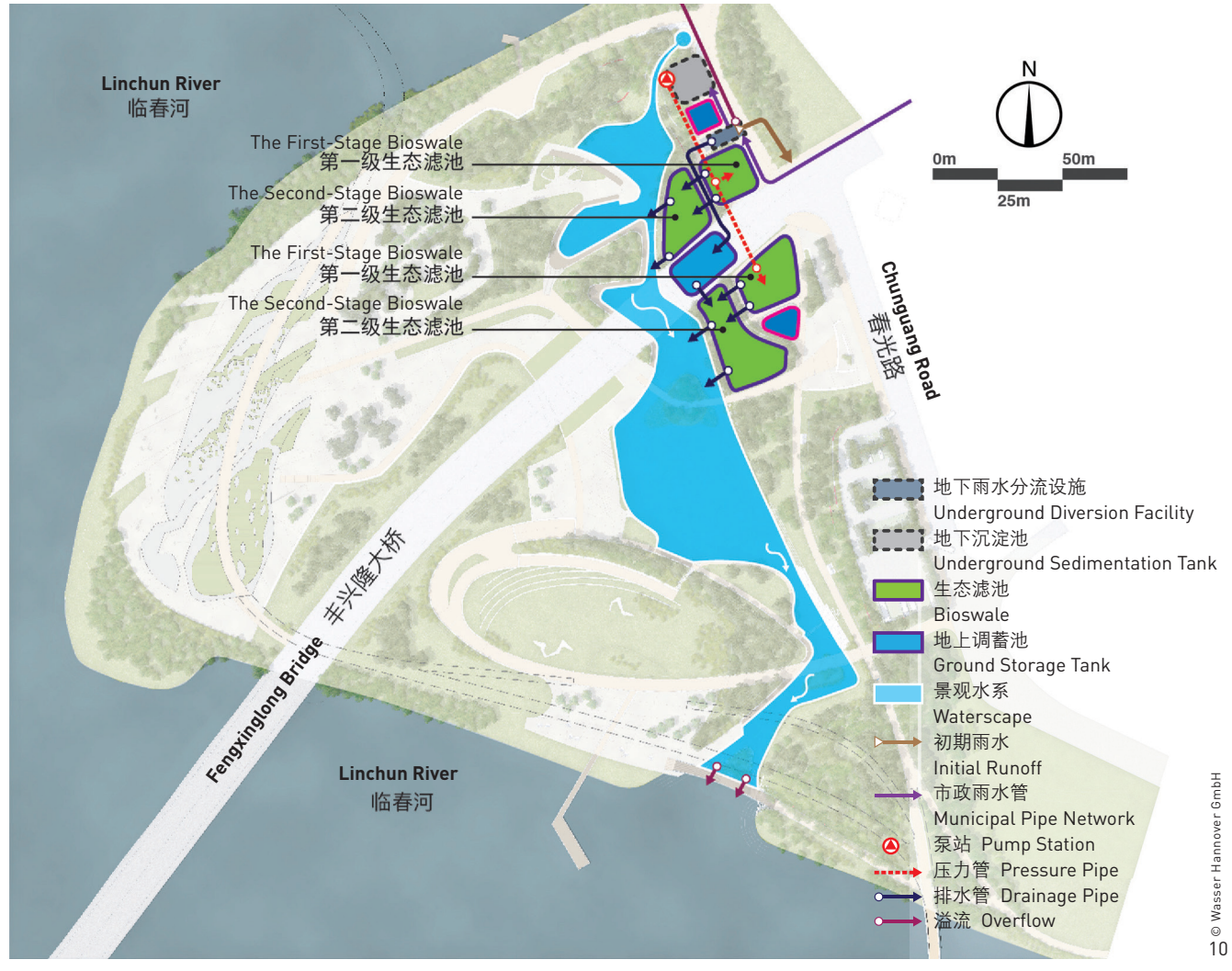

In total, the park can accommodate $398.25 \mathrm{~m}^{3}$ of total runoff $\left(298.25 \mathrm{~m}^{3}\right.$ by the rainwater facilities and $100 \mathrm{~m}^{3[5]}$ by the rainwater storage modules), which exceeds the expectation.

\subsection{Water Source and Water Quality Assurance System}

The total water area in the park is around $9,000 \mathrm{~m}^{2}$, with an additional $15,000 \mathrm{~m}^{2}$ of green area. Through assessment we found that the annual water consumption of the park is $136,095 \mathrm{~m}^{3}$ more than the existing water source provided in a year (Table 3). The water collected from April to November meets irrigation and consumption demands. From December to March, additional water sources may be introduced.

Lakes provide the main storage for rainwater on site. The southern lake covers an area of $6,260 \mathrm{~m}^{2}$ with $1,878 \mathrm{~m}^{3}$ for water storage. The northern lake, on the other hand, is a waterfall system and is unable to store rainwater. The rainwater collected by the southern lake provides irrigation for the landscape. When the stored rainwater cannot meet the water supply requirements, municipal water can also be brought in after purification in the bioswales and phosphorus removal ponds. ${ }^{[6][7]}$

表3: 项目区域月均水平衡表格

Table 3: The Difference between the Offering Water Source and Consumption

\begin{tabular}{|c|c|c|c|c|c|c|c|c|c|c|c|c|c|}
\hline $\begin{array}{l}\text { 月份 } \\
\text { Month }\end{array}$ & $\begin{array}{c}\text { 一月 } \\
\text { January }\end{array}$ & $\begin{array}{c}\text { 二月 } \\
\text { February }\end{array}$ & $\begin{array}{c}\text { 三月 } \\
\text { March }\end{array}$ & $\begin{array}{l}\text { 四月 } \\
\text { April }\end{array}$ & $\begin{array}{l}\text { 五月 } \\
\text { May }\end{array}$ & $\begin{array}{l}\text { 六月 } \\
\text { June }\end{array}$ & $\begin{array}{l}\text { 七月 } \\
\text { July }\end{array}$ & $\begin{array}{c}\text { 八月 } \\
\text { August }\end{array}$ & $\begin{array}{c}\text { 九月 } \\
\text { September }\end{array}$ & $\begin{array}{c}\text { 十月 } \\
\text { October }\end{array}$ & $\begin{array}{c}\text { 十一月 } \\
\text { November }\end{array}$ & $\begin{array}{c}\text { 十二月 } \\
\text { December }\end{array}$ & $\begin{array}{l}\text { 全年 } \\
\text { Year }\end{array}$ \\
\hline $\begin{array}{l}\text { 降雨量 } \\
\text { Precipitation } \\
\text { (mm) }\end{array}$ & 8.0 & 12.8 & 19.2 & 43.3 & 142.3 & 197.5 & 192.6 & 221.5 & 251.4 & 234.5 & 58.3 & 10.7 & 1392.1 \\
\hline $\begin{array}{c}\text { 可收集雨水资源量 } \\
\text { Harvested Raanwater } \\
\text { (m³/Mon) }\end{array}$ & $2,006.2$ & $3,209.9$ & $4,814.9$ & $10,858.6$ & $35,685.3$ & $49,528.1$ & $48,299.3$ & $55,546.7$ & $63,044.8$ & $58,806.7$ & $14,620.2$ & $2,683.3$ & $349,103.9$ \\
\hline $\begin{array}{c}\text { 可利用雨水资源量 } \\
\text { Available Water Resource } \\
\text { (m³/Mon) }\end{array}$ & $1,003.1$ & $1,605.0$ & $2,407.4$ & $5,429.3$ & $17,842.6$ & $24,764.0$ & $24,149.7$ & $27,773.4$ & $31,522.4$ & $29,403.4$ & $7,310.1$ & $1,341.6$ & $174,552.0$ \\
\hline $\begin{array}{c}\text { 蒸发量 } \\
\text { Evapotranspiration } \\
\text { (mm) }\end{array}$ & 184.0 & 164.0 & 198.0 & 215.0 & 235.0 & 205.0 & 214.0 & 194.0 & 177.0 & 192.0 & 195.0 & 190.0 & $2,363.0$ \\
\hline $\begin{array}{c}\text { 湖体蒸发量 } \\
\text { Water Evaporated from the Lake } \\
\text { (m³/Mon) }\end{array}$ & $1,656.0$ & $1,476.0$ & $1,782.0$ & $1,935.0$ & $2,115.0$ & $1,845.0$ & $1,926.0$ & $1,746.0$ & $1,593.0$ & $1,728.0$ & $1,755.0$ & $1,710.0$ & $21,267.0$ \\
\hline $\begin{array}{c}\text { 灌溉量 } \\
\text { Irrigation Volume (m³/Mon) }\end{array}$ & $2,760.0$ & $2,460.0$ & $2,970.0$ & $3,225.0$ & - & - & - & - & - & - & $2,925.0$ & $2,850.0$ & $17,190.0$ \\
\hline $\begin{array}{c}\text { 需水量 } \\
\text { Water } \\
\text { (anda }\end{array}$ & $4,416.0$ & $3,936.0$ & $4,752.0$ & $5,160.0$ & $2,115.0$ & $1,845.0$ & $1,926.0$ & $1,746.0$ & $1,593.0$ & $1,728.0$ & $4,680.0$ & $4,560.0$ & $38,457.0$ \\
\hline $\begin{array}{c}\text { 差额 } \\
\text { Shortfall (m³/Mon) }\end{array}$ & $-3,412.9$ & $-2,331.0$ & $-2,344.6$ & 269.3 & $15,727.6$ & $22,919.0$ & $22,223.7$ & $26,027.4$ & $29,929.4$ & $27,675.4$ & $2,630.1$ & $-3,218.4$ & $136,095.0$ \\
\hline
\end{tabular}

注：因为项目调蓄空间有限（只有南部水体），所以在计算时，按经验取可收集雨水资源量的 $50 \%$ 作为可利用雨水资源量，仅用作与需水量进行比对。

Note: $50 \%$ of the amount of harvested rainwater is represented as the avaliable water resouce, because that only the south lake, which covers about half of the park area, can be used to store water 
水景的水质会直接影响公共健康和景观体验, 因此该项目水体水 质目标定为 III 类地表水, 并计划建立一套完整的净化循环系统以长期 保持水质。设计在丰兴隆大桥南北两侧设置了蓄水型生态滤池, 通过 选用当地精选级配的中沙作为滤料, 并在其中种植芦苇 (Phragmites communis) 和美人蕉 (Canna indica) 等水生植物, 用以保持过滤层 疏松和吸收溶解性营养物质。另外, 针对三亚热带气候条件下低磷浓 度环境容易滋生藻类的问题, 设计还特别设立了除磷池。净化后的水 体沿着水系流向南部, 经由南部驳岸过滤系统净化, 并通过循环洜循 环输送至园区北部的不同设施中（图11)：一部分水体通过两个除磷 池进行净化处理; 一部分水被送至北部泉眼, 补给跌水溪流和其他水 景; 一部分则被送人北部湖体的三个湖湾，完成循环。 ${ }^{[8]}$

\section{4 结合种植设计打造游秘滨水空间}

总体植物设计上秉持 4 个原则, 包括形成连续的滨河红树林带、强化 节奏韵律的色彩搭配、注重季相变化, 以及强调宏观绿量和微观配置。

在基础水文数据和红楖林生境研究分析基础上, 结合场地特征, 确定公园滨河界面以连续的红树林景观为主, 并将小体量滨水空间点 缀其间。结合公园不同区段的高差、用地条件, 采用不同的驳岸空间 处理模式和恢复措施, 并根据水体含盐量, 确定红树林种植种类。

步行环廊设计强调对生态环境的最低干扰, 结合地形条件、红树 林分布、现状桥梁高度等因素, 分为空中栈桥、水上栈道、园路和建 筑屋顶4种灵活的形态, 可高处远眺, 可林间漫步, 可贴水而行, 创造 出了丰富的游览体验 ${ }^{[1]}$ 。

\section{6 结语}

经过近半年的试运行，丰兴隆生态公园的水系水质基本达到 III 类 水平, 化学需氧量、氨氮、总氮、总磷等指标均明显降低 (表4)。

从上述项目中我们可以得到一系列启发: 在城市公共空间设计中, 设计师应跳出红线设计范围, 综合性考虑公共空间在片区及城市中所应 承担的功能, 在有限的城市用地中融人更多的功能, 并最大限度地服务 于使用者。同时, 应以资源的集约利用为目标, 最大限度地降低城市 公共空间的管理和维护成本, 以及对各类资源的依赖和消耗。

丰兴隆生态公园项目不仅发挥了休闲游㰾之功用, 同时还起到 了雨水收集、调蓄、净化, 河流污染物削减, 以及降低洪涝隐患等作 用, 实现了生态修复和资源的集约利用, 成为了该汇水片区不可或缺 的 “城市海绵”, 以及综合性韧性生态公园的典范。LAF
The water quality of the waterscapes will directly affects the public health and landscape experience. Therefore, one of the design goals is to have the surface water meet the Class III standard and complete a long-term purification cycle. To meet this goal, bioswales are set up on either side of the Fengxinglong Bridge. Aquatic plants such as Phragmites communis and Canna indica planted inside the filters paved by selected local medium sand can keep the filter layer porous and absorb the dissolved nutrients. In addition, phosphorus removal ponds are introduced in to keep away algae that grows in the low-phosphorus tropical climate of Sanya. The water flows to the south and is purified by the filter system along the bank and pumped to different facilities in the northern part of the park through a circulating pump. As the Figure 11 shows, these facilities include two phosphorus removal ponds (to be purified once again), the spring (to supply water for the waterfall and other waterscapes) and three bays of the northern lake (to cycle back to the lake). ${ }^{[8]}$

\subsection{Create Waterfront Spaces through Planting}

The planting design is driven by four principles: 1) form a continuous riverfront mangrove belt; 2) arrange the color of trees to have a seasonal rhythm; 3) care about visual
11. 水源与水质保障系统技 术路线
11. Treatment process of the water source and water quality assurance system

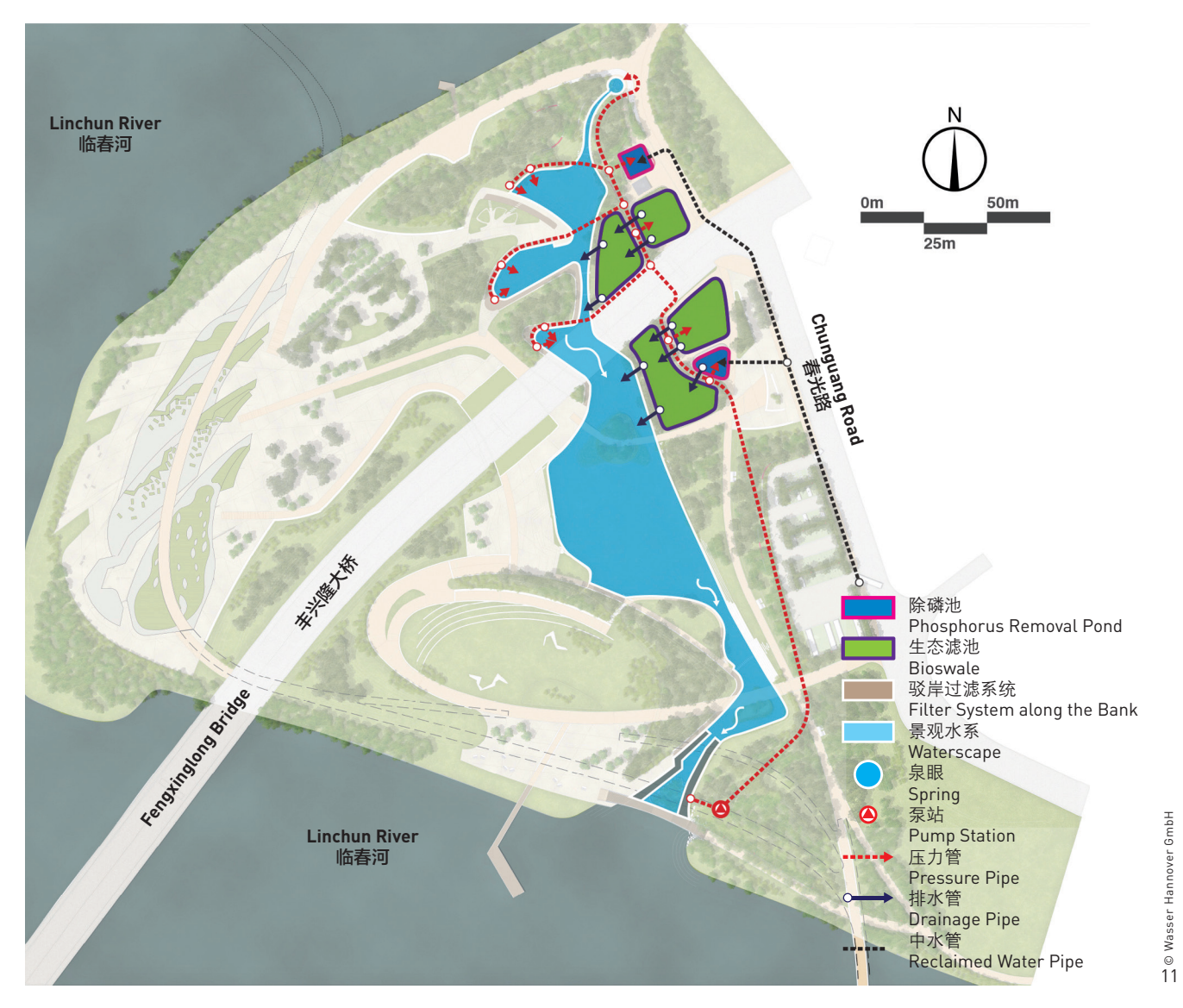


appearance in all seasons; and 4) focus on both overall greenness and detail plantings.

Based on hydrological data, research and analysis of mangrove habitat, and site conditions, the park's riversides are filled with continuous mangrove with small waterfront spaces dotted inside. The methods of placemaking and riverbank restoration vary due to different topographies and land uses. And the species of mangroves to be planted are connected with the salinity of the water body.

The circulation considers topography, mangroves distribution, and the Fengxinglong Bridge height to create routes with minimum disturbance to the ecological environment. Corridors formed by skywalks, water boardwalks, park lanes, and building roofs, create a variety of forest and water experiences ${ }^{[1]}$.

\section{Conclusion}

After nearly six months of trial operation, the water quality of the Fengxinglong Ecological Park has reached the standard of Class III Surface Water. Table 4 shows that COD, $\mathrm{NH}_{3}-\mathrm{N}, \mathrm{TN}$, and TD levels all decreased sharply compared to Table 2.

The design of the Fengxinglong Ecological Park teaches us to consider the role of a site within its broader context and to layer functions to provide the most services and spaces to its users. By using resources more intentionally, we can reduce management and maintenance costs in urban public spaces, as well as relieve the dependence and consumption of various resources.

The park catches, stores, and purifies rainwater to reduce river pollution and flooding disasters in addition to offering recreational function. As a valuable "urban sponge" and a comprehensive resilient ecological park, it has helped restore the historic ecosystem and realized the intensive use of resources. LAF
表4：丰兴隆生态公园水质监测报告 (三亚市环境监测站) Table 4: Monitoring Report of the Water Quality of the Fengxinglong Ecological Park by Sanya Environmental Monitoring Station

\begin{tabular}{|c|c|c|c|}
\hline $\begin{array}{c}\text { 监测时段 } \\
\text { Monitoring Time }\end{array}$ & \multicolumn{3}{|c|}{$\begin{array}{l}\text { 2017年4月14 15日 } \\
\text { April 14 15, } 2017\end{array}$} \\
\hline $\begin{array}{l}\text { 样品特征 } \\
\text { Features }\end{array}$ & \multicolumn{3}{|c|}{$\begin{array}{l}\text { 水质清; 无味 } \\
\text { Clear and Odor Free }\end{array}$} \\
\hline $\begin{array}{c}\text { 采样点 } \\
\text { Sampling Location }\end{array}$ & $\begin{array}{c}\text { 测试项目 } \\
\text { Monitoring Indicator }\end{array}$ & $\begin{array}{c}\text { 测试结果 } \\
\text { Result }\end{array}$ & $\begin{array}{c}\text { 水质类别 } \\
\text { Water Quality Level }\end{array}$ \\
\hline \multirow{8}{*}{$\begin{array}{c}\text { 丰兴隆生态公园南侧 } \\
\text { 景观湖 } \\
\text { South Lake of } \\
\text { Fengxinglong } \\
\text { Ecological Park }\end{array}$} & $\begin{array}{l}\text { 水温 } \\
\mathrm{T}\left({ }^{\circ} \mathrm{C}\right)\end{array}$ & 30 & \multirow{8}{*}{ Class III } \\
\hline & $\begin{array}{c}\text { 酸碱度 } \\
\mathrm{pH}\end{array}$ & 8.29 & \\
\hline & $\begin{array}{c}\text { 氨氮 } \\
\mathrm{NH}_{3}-\mathrm{N}(\mathrm{mg} / \mathrm{L})\end{array}$ & 0.17 & \\
\hline & $\begin{array}{l}\text { 总氮 } \\
T N(\mathrm{mg} / \mathrm{L})\end{array}$ & 0.93 & \\
\hline & $\begin{array}{l}\text { 总磷 } \\
\operatorname{TP}(\mathrm{mg} / \mathrm{L})\end{array}$ & 0.07 & \\
\hline & $\begin{array}{l}\text { 溶解氧 } \\
\text { DO } \mathrm{mg} / \mathrm{Ll})\end{array}$ & 8.9 & \\
\hline & $\begin{array}{l}\text { 化学需氧量 } \\
\operatorname{COD}(\mathrm{mg} / \mathrm{L})\end{array}$ & 14 & \\
\hline & $\begin{array}{l}\text { 高镉酸盐指数 } \\
\operatorname{CODMn}(\mathrm{mg} / \mathrm{L})\end{array}$ & 3 & \\
\hline $\begin{array}{l}\text { 备注 } \\
\text { Note }\end{array}$ & \multicolumn{3}{|c|}{$\begin{array}{c}\text { 评价标准: 《地表水环境质量标准》 ( GB3838-2002) } \\
\text { Reference: Environmental Quality Standard for Surface Water (GB3838-2002) }\end{array}$} \\
\hline
\end{tabular}

\section{REFERENCES}

[1] Ma, H. R., Song, C. L., \& Qi, S. S. (2017). Waterfront Green Space Design Based on Ecological Restoration:A Case Study of Sanya's Two Rivers and Feng Xinglong Ecological Park. Urban and Rural Planning, (3), 65-75, doi: 10.12049 /j. urp. 201703009

[2] Gujer, W. (2007). Siedlungswasserwirtschaft. Berlin Heidelberg: Springer-Verlag.

3] Schwoerbel. J., \& Brendelberger. H. (2013). Einführung in die Limnologie. Berlin Heidelberger: Springer-Verlag.

[4] Zhao, Q. S. (2016, June 29). Fengxinglong Ecological Park - the Green Precious Stone Located in the Intersection of Sanya River and Linchun River, Sanya. Sanyadaily. Retrieved from http://epaper sanyarb.com.cn/htm//2016-06/29/content_2_2.htm

5] Lu, L. P. (2017). Study on the Sponge City Construction Practice of City Park. Municipal Engineering Technology, (4), 172-174.

[6] Yudelson, J. (2010). Dry Run: Preventing The Next Urban Water Crisis. Canada: New Society Publishers.

[7] Mehlhart, G. (2001). Grauwasser-Recycling international - Internationale Anforderungen und Projektbeispiele aus zehn Ländern. Regenwassernutzung und -bewirtschaftung im internationalen Kontext, (8), 277-295.

[8] Wilkens, A., Dreiseitl, H., Greene, J., Jacobi, M., Liess, C., \& Schwenk, W. (2009). Wasser bewegt: Phänomene und Experimente. Bern, Stuttgart, Wien: Haupt Verlag. 